Annals of Warsaw University of Life Sciences - SGGW

Horticulture and Landscape Architecture No 39, 2018: 71-81

(Ann. Warsaw Univ. of Life Sci. - SGGW, Horticult. Landsc. Architect. 39, 2018)

DOI 10.22630/AHLA.2018.39.7

\title{
Spatial analysis of agricultural greenhouse gas emission at the municipality (LAU-2) level across Poland
}

\author{
ELŻBIETA WÓJCIK-GRONT, MARCIN OLLIK
}

Faculty of Agriculture and Biology, Warsaw University of Life Sciences - SGGW

\begin{abstract}
Spatial analysis of agricultural greenhouse gas emission at the municipality (LAU-2) level across Poland. Poland is obliged to report annually the total of the country's GHG emission in the form of the National Greenhouse Gas Inventory Report (NIR) to the secretariat of the United Nations Framework Convention on Climate Change (UNFCCC). The total emission comes from several sectors of the economy. One of the sectors is agriculture. In the presented work, the Intergovernmental Panel on Climate Change (IPCC) methodology was adapted to estimate the spatial distribution of Polish agricultural greenhouse gas (GHG) emission at the municipality (LAU-2) level. The amount of methane, nitrous oxide and carbon dioxide emitted from agriculture in each of 2,173 municipalities was calculated. Then the results were converted to the amount of carbon dioxide equivalents, summed up, and the total agricultural emission in each municipality was obtained. In the calculations, the authors used available data on farm resources, farming and land cover characteristics collected through the National Agricultural Census conducted in 2010 by the Central Statistical Office of Poland (GUS) aggregated at the LAU-2 level. The results were mapped and the spatial distribution of GHG emitted from agriculture at the LAU-2 level was obtained for the first time for Poland. Selected regions with a high GHG emission are Podlasie and Wielkopolska. The high emission in these regions is associated with high livestock and crop production.
\end{abstract}

Key words: spatial distribution, GHG, GWP, agriculture, UNFCCC, IPCC

\section{INTRODUCTION}

Anthropogenic greenhouse gas (GHG) emission is the predominant cause of climate change as GHGs affect the atmosphere by chemical changes and therefore can cause global warming (IPCC 2007). One of the GHG emissions sources, a result of human activity, is the agricultural sector. The overall agricultural emission to the global estimated emission constitutes over $10 \%$. Agriculture is the world's biggest emitter of methane $\left(\mathrm{CH}_{4}\right)$ and nitrous oxide $\left(\mathrm{N}_{2} \mathrm{O}\right)$ that comes from anthropogenic sources (Smith et al. 2007). In the agricultural sector most of the methane is expelled as a byproduct from enteric fermentation in livestock breeding (Hassanat and Benchaar 2016). Methane is also emitted from manure management that consists of manure capture, storage, handling and utilization (Davidson 2009). Nitrous oxide is also emitted from manure management but mostly from agricultural soils (Smith and Conen 2004, Oenema et al. 2005). In agriculture there is also $\mathrm{CO}_{2}$ emitted, during soil liming, but its contribution to the total GHG emission from agriculture is small. 
Nowadays, the mitigation of GHG emissions is a challenge for European countries. In 2016 the European Commission presented a legislative proposal for the period 2021-2030, the "Effort Sharing Regulation", stating that emission reductions should also regard agriculture (now not covered in the European Union Emissions Trading System - the EU ETS). Moreover, agriculture is not included in the local low carbon economy plans of municipalities, which are created to prepare a background for the successful application to receive EU funds. More attention is received by other sectors like energy, processes or transport.

For comparison purposes, each GHG's Global Warming Potential (GWP) can be expressed in $\mathrm{CO}_{2}$ eq, meaning how much higher a gas GWP is in comparison to one particle of $\mathrm{CO}_{2}$ (Lashof and Ahuja 1990). It depends on the gas's absorption of radiation, its absorbing wavelengths and its lifetime in the atmosphere. The Global Warming Potential (GWP) of $\mathrm{CH}_{4}$ is $25 \mathrm{CO}_{2}$ eq (25 times higher than for $\mathrm{CO}_{2}$ ) and $298 \mathrm{CO}_{2}$ eq for $\mathrm{N}_{2} \mathrm{O}$ in a 100 year's time horizon (IPCC 2007).

Since 1994, Poland has been a party to the United Nations Framework Convention on Climate Change (UNFCCC) and joined the international efforts aiming at mitigating climate change by entering the Kyoto Protocol in 2002. Thus, Poland is obliged to reduce its greenhouse gas emissions in relation to the base year 1988. Emissions of GHGs are estimated using the methodologies provided by the Intergovernmental Panel on Climate Change (IPCC) in 2006. In the IPCC methodology for the estimation of GHG emission at the country level (IPCC 2006) there are included different sectors of a country's economy. One of the sectors covered by the IPCC methodology for estimating GHG emission is agriculture. According to the calculations conducted in compliance with the IPCC methodology (IPCC 2006, Wójcik-Gront and Gront 2014, Wójcik-Gront 2015, NIR 2017), agriculture in 2010 was responsible for around one tenth of the total Polish GHG emission (Fig. 1).

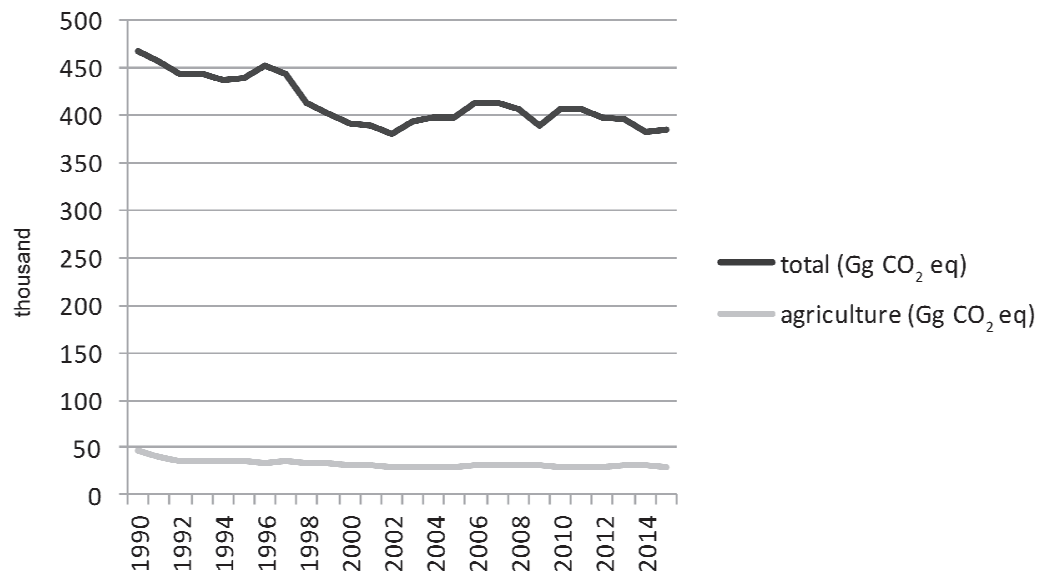

FIGURE 1. Polish total and agricultural emission $\mathrm{Gg} \mathrm{CO}_{2}$ eq from 1990 to 2015 (NIR 2017) 
The total of the Polish GHG emission in 2010 reported to the United $\mathrm{Na}$ tions Framework Convention on Climate Change (UNFCCC) accounted for $407 \mathrm{Mt} \mathrm{CO}_{2}$ eq. Agricultural GHG emission was equal to $30 \mathrm{Mt} \mathrm{CO}_{2}$ eq. Total agricultural emission has been decreasing since the 1990s of the last century (Fig. 1). In Poland agricultural GHG emission sources contain enteric fermentation, manure management, agricultural soils, field burning of agricultural residues, liming and urea application (Fig. 2). Enteric fermentation is a source of methane emission and regards livestock. Manure management, a source of methane and nitrous oxide emission also regards livestock. Agricultural soils are a source of nitrous oxide emission which comes from direct $\mathrm{N}_{2} \mathrm{O}$ emission from managed soils, together with indirect $\mathrm{N}_{2} \mathrm{O}$ emissions from managed soils which is atmospheric deposition, nitrogen leaching and run-off. Field burning of agricultural residues is a source of methane and nitrous oxide emission but its share in the total agricultural emission is very small
- around 0.1\% (Fig. 2). In 2010, agricultural methane emission accounted for over $28 \%$ of the total methane emission estimated for Poland. Share of $87 \%$ of the agricultural methane emission comes from enteric fermentation. Agricultural nitrous oxide emission accounted for $74 \%$ of the total nitrous oxide emission estimated for Poland and mostly $(86 \%)$ comes from agricultural soils. Manure management constitutes $13 \%$ of the agricultural methane emission and $14 \%$ of the agricultural nitrous oxide emission. When it comes to the main gasses emitted from the agricultural sector in 2010, the $\mathrm{N}_{2} \mathrm{O}$ emission share was the largest in the total $\mathrm{GHG}$ emission (50\%), then methane $(47.4 \%)$ and eventually carbon dioxide $(2.6 \%)$ - Figure 3.

In this work the authors were interested in investigating the patterns according to which the agricultural emission is spread across the whole of Poland. The data from the last National Agricultural Census collected in 2010 by the Central Statistical Office of Poland were analyzed for each municipality to calculate

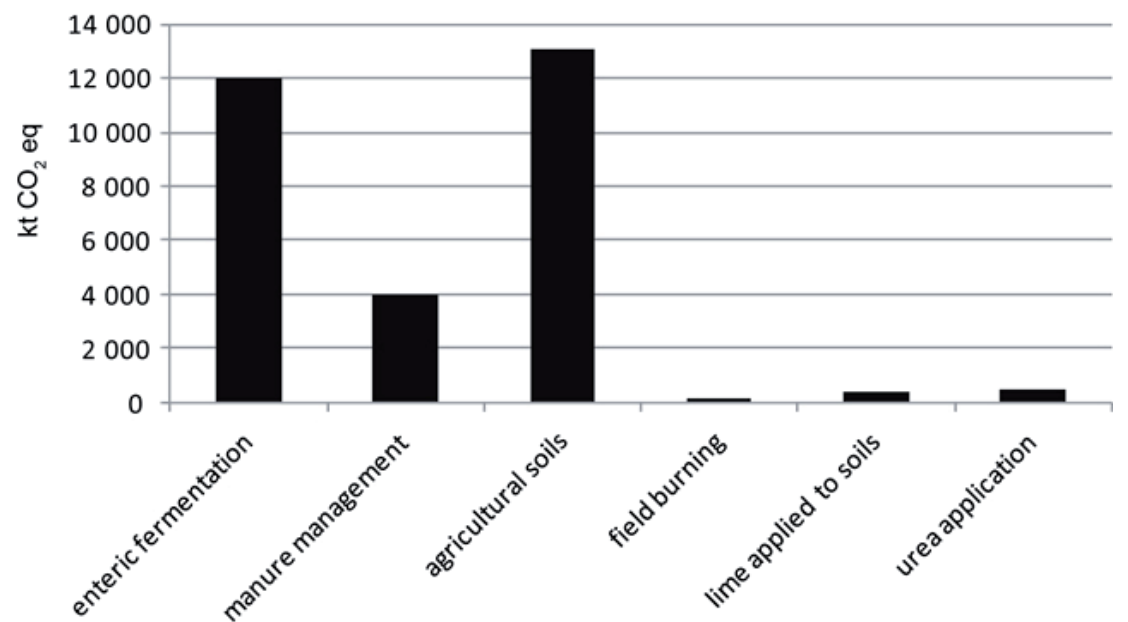

FIGURE 2. Emission of GHG from all sources of agricultural emission in Poland in 2010 (NIR 2017) 


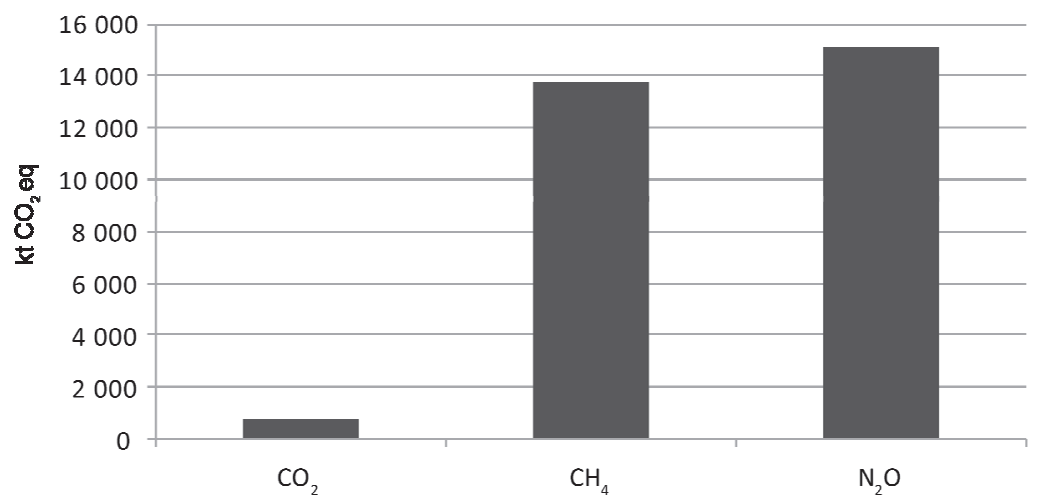

FIGURE 3. Types and structure of GHGs emitted from agriculture in Poland in 2010 (NIR 2017)

the total agricultural emission and the emissions of methane, nitrous oxide and carbon dioxide from agriculture in each of 2,173 Polish municipalities (LAU-2 units). Then, based on the calculations, maps of the total GHG emission from agriculture and for each GHG type emitted from this sector were created for the first time for the whole of Poland at the municipality level.

\section{MATERIAL AND METHODS}

The agricultural emission from each municipality was estimated based on the IPCC methodology (IPCC 2006, Wójcik-Gront and Gront 2014, Wójcik-Gront 2015, NIR 2017). The methodology is based on multiplying an activity by its emission factor. Activity is the number of one type of animals living in a municipality in 2010 (for example, the number of swine). In this work, the activity data was taken from the National Agricultural Census conducted in 2010. Unfortunately, some data are missing in this census like data on the sheep population in 2010. Also, based on the data, for cattle the only distinction possible was between dairy and non-dairy cattle. There were no data on fur-bearing animals. The emission factor is the amount of GHG produced by this activity in 2010: for example, the amount of methane from swine manure management. The values for the year 2010 were taken from the latest National Inventory Report (NIR 2017) obtained based on the IPCC methodology. Emission factors were the same for all municipalities. In many cases country specific data on animal and feed characteristics were used to obtain an emission factor in 2010, but sometimes default emission factors were used.

Methane emission factors in enteric fermentation were estimated based on Polish specifics for dairy cattle and the rest of cattle (Eq. 1) and default values from the IPCC were used for swine and horses. Other animals were not considered in this work due to the lack of data available at the municipality level. These emission factors are calculated assuming an appropriate average daily feed intake (gross energy), which depends on the energy used for maintenance, activity, 
lactation, growth and pregnancy of a type of animal and the methane conversion rate which is a fraction of the feed energy converted to methane. The emission factors for enteric fermentation are presented in the table.

$E F=\left(G E \times \frac{Y m}{100} \times 365\right) / 55.65$

where:

$E F$ - emission factor ( $\mathrm{kg} \mathrm{CH}_{4} /$ head/ /year);

$E$ - gross energy intake (MJ/head/day);

$\mathrm{Ym}$ - methane conversion rate, percent of gross energy in feed converted to methane $(\%)$;

$55.65 \mathrm{MJ} / \mathrm{kg} \mathrm{CH}_{4}$ - energy content of methane.

The next source of agricultural emission is manure management. Methane emissions related to animal manure management come mostly from manure generated by cattle (around 50\%) and swine (around 40\%). Emission factors for the methane and nitrous oxide from manure management were calculated based on average daily volatile excreted solids, the maximum $\mathrm{CH}_{4} / \mathrm{N}_{2} \mathrm{O}$ production capacity for manure produced by an animal and the conversion factors for each manure management system for a cool climate. To calculate the emission from manure management, the animal waste management systems structure for each animal group, i.e. the share of pastures and solid storage, was estimated. There were also a few default values from the IPCC methodology used. In the case of $\mathrm{N}_{2} \mathrm{O}$ emissions from manure management there is also indirect emission from atmospheric nitrogen deposition and nitrogen leaching and runoff, where de- fault values were adopted. The emission factors calculated for the $\mathrm{CH}_{4}$ and $\mathrm{N}_{2} \mathrm{O}$ gases from manure management are presented in the table.

A major part of the $\mathrm{N}_{2} \mathrm{O}$ emissions is related to direct soil cultivation. This includes inorganic $\mathrm{N}$ fertilizers applied to soils, organic $\mathrm{N}$ fertilizers' use (animal manure and sewage sludge), urine and dung deposited by grazing animals, crop residues and the cultivation of organic soils.

In the presented study there was no data on the cultivation of organic soils at the municipality level, thus this source (constituting around 20\% of the direct $\mathrm{N}_{2} \mathrm{O}$ emission from soil cultivation) was not included in the calculations.

Indirect $\mathrm{N}_{2} \mathrm{O}$ emissions from managed soils comes from atmospheric deposition and nitrogen leaching and run-off from the use of synthetic fertilizers, as well as from organic additions to soils (livestock manure and sewage sludge). All of the activities are expressed in amounts of nitrogen applied to soils. The emission factors for direct and indirect $\mathrm{N}_{2} \mathrm{O}$ emission from $\mathrm{N}$ inputs are presented in the table. The amount of methane and nitrous oxide emission coming from the field burning of agricultural residues was calculated using activity data on crop production and the default emission factors from the IPCC methodology (the table). This source contributes the least to total agricultural emission.

The only source of $\mathrm{CO}_{2}$ emission considered here comes from agricultural lime application and is calculated based on the amount of lime used in a municipality and the default IPCC emission factor (the table). 
TABLE. Emission factors used in the agricultural municipality emission calculations

\begin{tabular}{|c|c|}
\hline Source of emission in agriculture & $\begin{array}{c}\text { Value of emission factor } \\
\text { used }\end{array}$ \\
\hline \multicolumn{2}{|l|}{ Enteric fermentation $\mathrm{CH}_{4}(\mathrm{~kg}$ of a gas/head $)$} \\
\hline - dairy cattle & 112.44 \\
\hline - non-dairy cattle & 49.31 \\
\hline- swine & 1.50 \\
\hline- horses & 118.00 \\
\hline \multicolumn{2}{|l|}{ Manure management $\mathrm{CH}_{4}(\mathrm{~kg}$ of a gas/head $)$} \\
\hline - dairy cattle & 10.77 \\
\hline - non-dairy cattle & 2.16 \\
\hline - swine & 2.04 \\
\hline- horses & 1.56 \\
\hline- poultry & 0.03 \\
\hline \multicolumn{2}{|c|}{ Manure management $\mathrm{N}_{2} \mathrm{O}$ : direct + indirect emission $(\mathrm{kg}$ of a gas/head) } \\
\hline - dairy cattle & 1.19 \\
\hline - non-dairy cattle & 0.51 \\
\hline- swine & 0.16 \\
\hline- horses & 0.77 \\
\hline - poultry & 0.005 \\
\hline $\mathrm{N}_{2} \mathrm{O}$ emissions from managed soils ( $\mathrm{kg}$ of a gas $/ \mathrm{kg} \mathrm{N}$ input) & 0.02 \\
\hline $\mathrm{CO}_{2}$ emissions from liming ( $\mathrm{kg}$ of a gas $/ \mathrm{kg} \mathrm{N}$ input) & 0.12 \\
\hline
\end{tabular}

Based on the available data on activities from the census, this work covers $87 \%$ of the total agricultural emission estimated for Poland for 2010. After calculating the total agricultural emission in each municipality, a simplified method with error propagation was used to estimate the uncertainty of the results (Wójcik-Gront and Gront 2014, Wójcik-Gront 2015). The uncertainty of the emission from agriculture in each municipality was set to be $\pm 40 \%$.

Maps showing the total agricultural emission, methane, nitrous oxide and carbon dioxide in each of 2,173 Polish municipalities for 2010 were made with QGIS 2.1.

\section{RESULTS AND DISCUSSION}

The results on the total agricultural emission in 2,173 Polish municipalities for 2010 expressed in $\mathrm{kt}$ of $\mathrm{CO}_{2}$ eq are presented in Figure 4. The amount of total agricultural emission depends mostly on the area of agricultural soils in a municipality, the main source of nitrous oxide emission, and the number of livestock, especially dairy and non-dairy cows emitting methane. Most of the areas with a low agricultural emission are distributed across southeast Poland, especially in places with low-intensity farming and areas with natural handicaps like slopes and a harsh climate acting against in- 


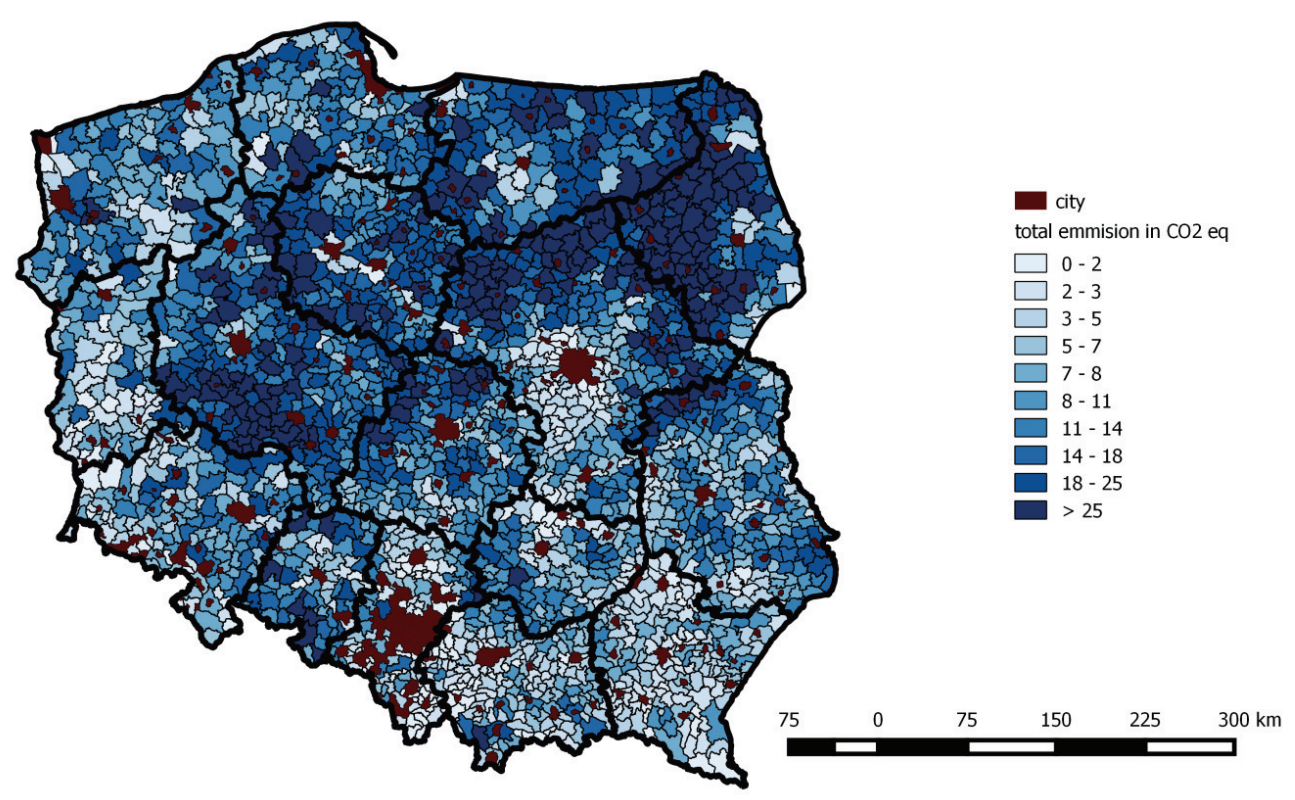

FIGURE 4. Total equivalent of carbon dioxide agricultural emission in Polish municipalities in 2010

tensive agriculture (Keenleyside et al. 2014).

This is the case in the Carpathian Mountains and Foothills and Świętokrzyskie Mountains (Kondracki 2000). The low intensive agriculture can be also explained by poor fertility soils, like in places around a small number of cities like Warsaw, Radom, Częstochowa, Katowice (Marcinek et al. 2011). Another region with low agricultural emission was identified in northwest Poland, e.g. the Pomeranian Lakelands and Puszcza Rzepińska. There is a high share of forest and extensive farming systems caused by a low soil fertility and landscape undulation (Marcinek et al. 2011). High agricultural emission is observed in areas in northeast Poland, however, in Podlasie. This region is characterized by high intensity dairy and meat farming systems (Petrick and Tyran 2003, Castel et al. 2010). The second re- gion with a high agricultural emission is observed in the west-central part of the country (Wielkopolska). Here good fertility soils allow to develop high intensity farming systems (Litwińczuk and Grodzik 2014). The highest agricultural emission was observed in the municipality of Wierzchowo in the West Pomeranian voivodeship, in north-western Poland. Data used in the analysis show that this highest agricultural GHG emission is associated mostly with methane emission which comes from the exceptionally high number of swine in this municipality.

In Figure 5 is presented the distribution of methane emissions across Poland at the LAU-2 level. The region in Poland mostly responsible for methane emission is Podlasie (north-east). As mentioned earlier, this GHG emission comes mostly from meat and dairy production (Castel et al. 2010). The methane emis- 


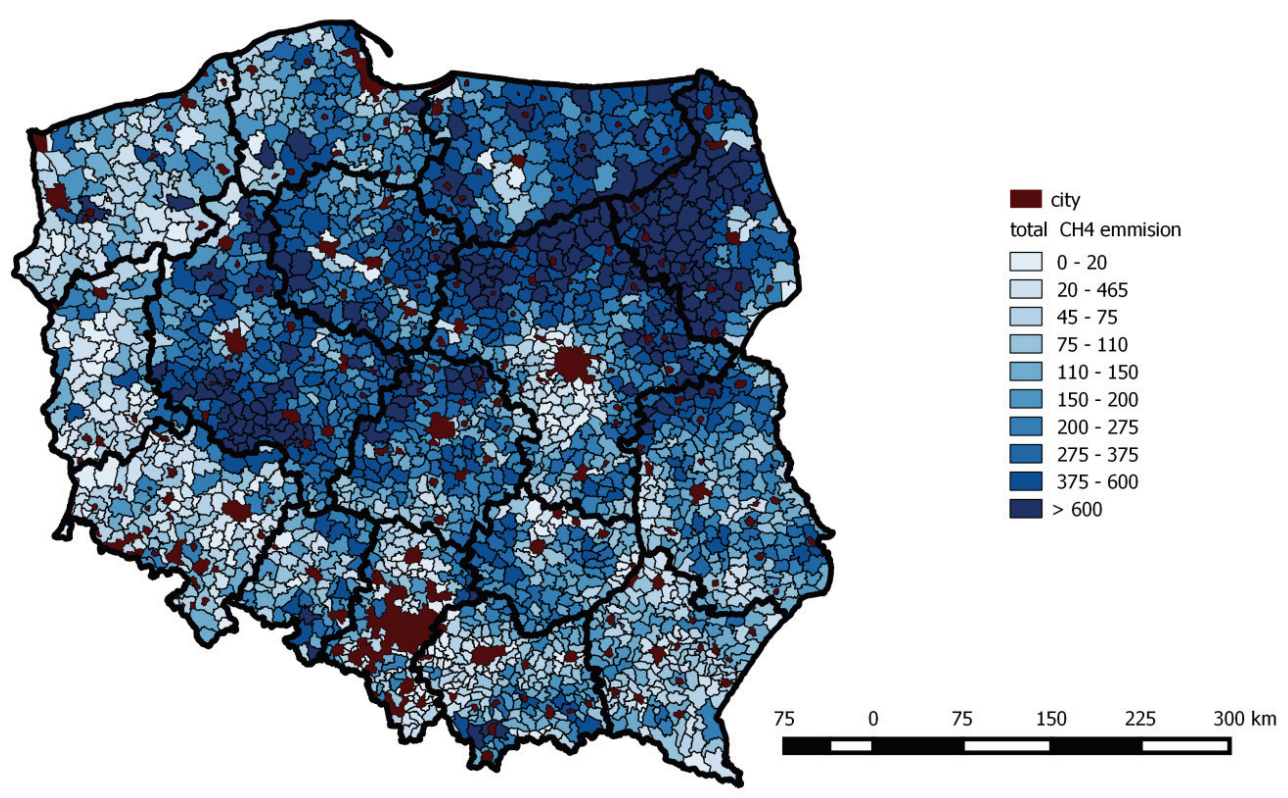

FIGURE 5. Total methane agricultural emission in Polish municipalities in 2010

sion from enteric fermentation depends mostly on the amount of dairy and nondairy cows living in a municipality. The highest emission was noticed also in the municipality of Wierzchowo due to swine production, which influenced the total agricultural emission from this municipality. The methane emission from the field burning of agricultural residues does not influence the distribution of agricultural $\mathrm{CH}_{4}$ emission in Poland.

In Figure 6 is presented the distribution of nitrous oxide emission across Poland at the LAU-2 level. Agricultural $\mathrm{N}_{2} \mathrm{O}$ emission comes mostly from direct soil cultivation (Decock et al.2015). High agricultural $\mathrm{N}_{2} \mathrm{O}$ emission is observed in west-central and northeast Poland due to the high intensity farming systems in these regions. The highest $\mathrm{N}_{2} \mathrm{O}$ emission was noticed in the municipality of Głubczyce in the Opole Voivodeship, in south-western Poland. According to the data used, it is associated with an exceptionally high cultivation area in this municipality. The nitrous oxide emission from the field burning of agricultural residues does not influence the distribution of agricultural $\mathrm{N}_{2} \mathrm{O}$ emission in Poland.

In agricultural emission, carbon dioxide comes from lime applied to soils. As can be seen in Figure 7 most of the agricultural $\mathrm{CO}_{2}$ is emitted in municipalities located in west Poland. This can be explained by the area's higher agricultural intensity regarding crop production and thus the higher use of agricultural resources including lime (Nowak and Wójcik 2015). Identifying regions with their leading agricultural GHG, following their specific farming system, can improve targeting the mitigation options preventing climate change by lowering the emissions.

The maps in this work have been created for the first time in Poland. In the 


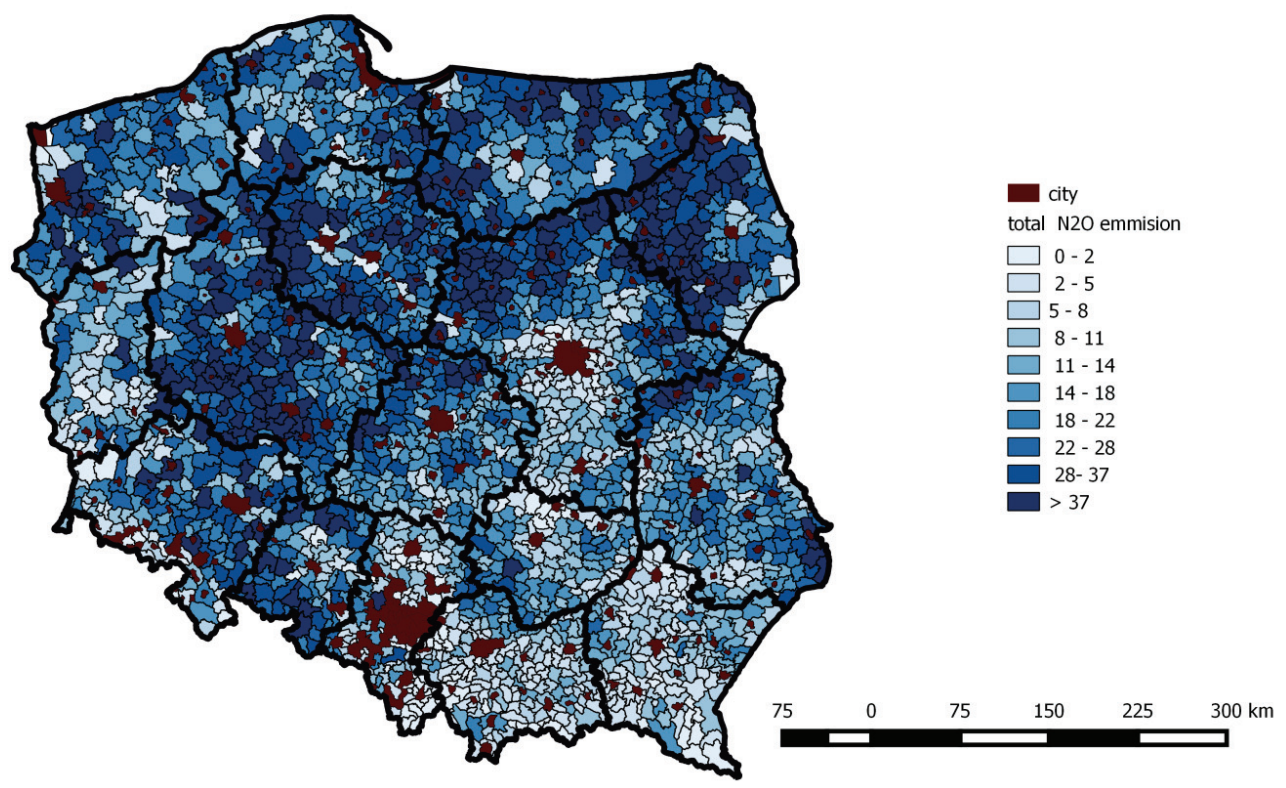

FIGURE 6. Total nitrous oxide agricultural emission in Polish municipalities in 2010

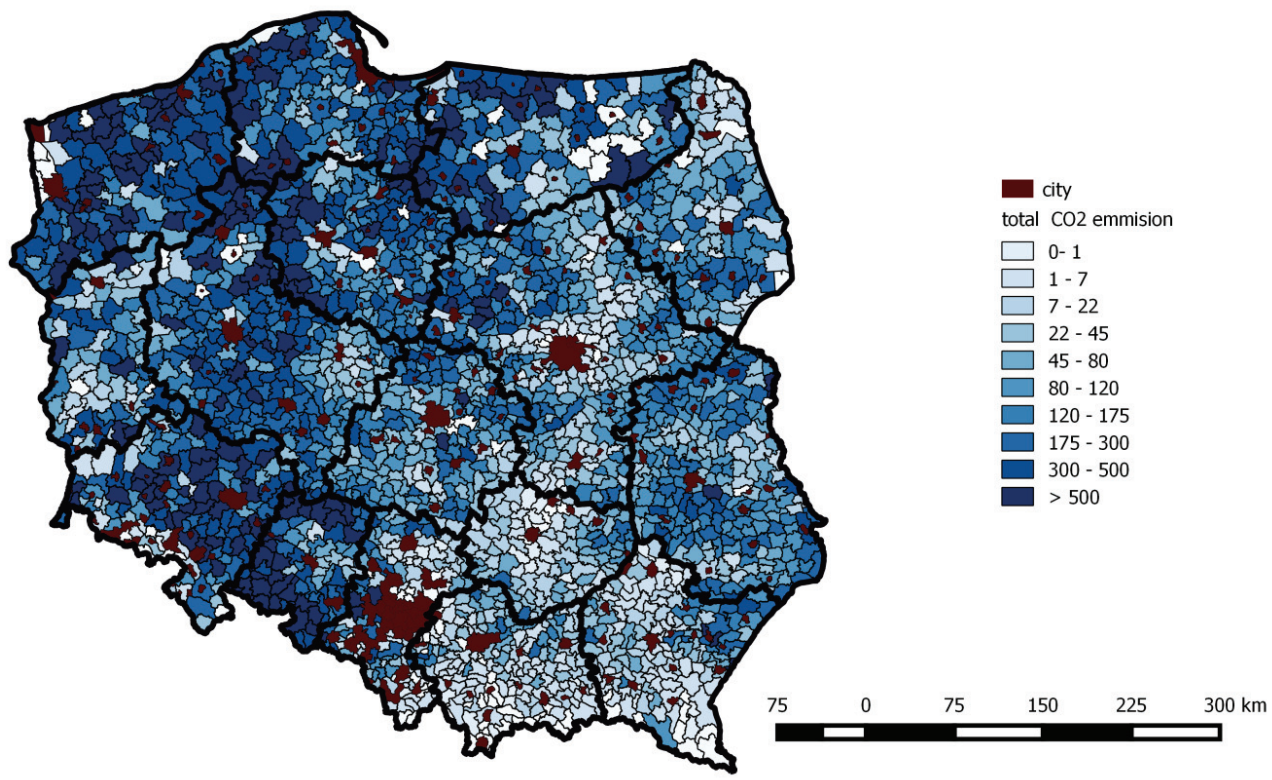

FIGURE 7. Total carbon dioxide agricultural emission in Polish municipalities in 2010 
authors' opinion the municipality is a unit small enough to see gradients in the GHG emission and differences between several regions in Poland. An even better resolution of the emission would give individual farm-based data providing information about the agriculture specific inside a municipality. However, this data was not available as during the census data collection the data from individual farms were aggregated.

\section{CONCLUSIONS}

Based on the calculations regarding agricultural emission in Polish municipalities, regions with high and low emission were identified. There are regions where methane emission is predominant, which points to mostly cattle and to a lesser extent swine intensive production. The area with a high $\mathrm{CH}_{4}$ emission is the Podlasie region. In areas with intensive crop production, high $\mathrm{N}_{2} \mathrm{O}$ emission is observed which regards high nitrogen usage. The area with a high nitrous oxide emission is the Wielkopolska region. Most of the agricultural carbon dioxide is emitted in municipalities located in west Poland, with higher agricultural intensity regarding crop production and thus higher use of lime.

\section{REFERENCES}

CASTEL J.M., MĄDRY W., GOZDOWSKI D., ROSZKOWSKA-MĄDRA B., DĄBROWSKI M., LUPA W., MENA Y. 2010: Family dairy farms in the Podlasie province, Poland: farm typology according to farming system. Span. J. Agric. Res. 8: 946-961.
DAVIDSON E.A. 2009: The contribution of manure and fertilizer nitrogen to atmospheric nitrous oxide since 1860. Nat. Geosci. 2: 659-662.

DECOCK C., LEE J., NECPALOVA M., PEREIRA E.I.P., TENDALL D.M., SIX J. 2015: Mitigating $\mathrm{N}_{2} \mathrm{O}$ emissions from soil: from patching leaks to transformative action. Soil 1 (2): 687-694.

HASSANAT F., BENCHAAR C. 2016: Effect of forage source of dairy cow diets on methane emission from enteric fermentation and manure storage. J. Anim. Sci. 94: 570-571.

IPCC 2006: IPCC Guidelines for National Greenhouse Gas Inventories.

IPCC 2007: IPCC Fourth Assessment Report (AR4), Climate Change 2007: Working Group I: The Physical Science Basis.

KEENLEYSIDE C., BEAUFOY G., TUCKER G., JONES G. 2014: High Nature Value farming throughout EU-27 and its financial support under the CAP. Report Prepared for DG Environment. Contract ENV B.1/ETU/2012/0035. Institute for European Environmental Policy, London.

KONDRACKI J. 2000: Regionalizacja fizycznogeograficzna Polski [Regional geography of Poland]. PWN, Warszawa.

LASHOF D.A., AHUJA D.R. 1990: Relative contributions of greenhouse gas emissions to global warming. Nature 344: 529-531.

LITWIŃCZUK Z., GRODZIK H. 2014: Stan hodowli i chowu bydła w Polsce oraz czynniki warunkujące rozwój tego sektora. Prz. Hod. 6: 1-5.

MARCINEK J., KOMISAREK J., BEDNAREK R., MOCEK A., SKIBA S., WIATROWSKA K. 2011: Systematyka gleb Polski. Soil Sci. Ann. 62 (3): 5-142.

NIR 2017. Poland's National Inventory Report 2014: Greenhouse Gas Inventory for 1988-2015. Submission under the UN Framework Convention on Climate Change and its Kyoto Protocol. Reporting entity: National Centre for Emission Management (KOBiZE) at the Institute 
of Environmental Protection - National Research Institute.

NOWAK A., WÓJCIK E. 2015: Regional differenctiation of production factors productivity in rural farms of Poland. Zagad. Doradz. Roln. 2: 43-55.

OENEMA O., WRAGE N., VELTHOF G.L., van GROENIGEN J.W., DOLFING J., KUIKMAN P.J. 2005: Trends in global nitrous oxide emissions from animal production systems. Nutr. Cyc Agroecosys. 72: 51-65.

PETRICK M., TYRAN E. 2003: Development perspective of subsistence farmers in Southeastern Poland: Social buffer stock or commercial agriculture. In: S. Abele, K. Frohberg (Eds.) Subsistence agriculture in Central and Eastern Europe: How to break the vicious circle. Conference Proceedings IAMO, Halle: 107-123.

SMITH K.A., CONEN F. 2004: Impacts of land management on fluxes of trace greenhouse gases. Soil Use and Manag. 20: 255-263.

SMITH P., MARTINO D., CAI Z., GWARY D., JANZEN H., KUMAR P., McCARL B., OGLE S., O'MARA F., RICE C., SCHOLES B., SIROTENKO O. 2007: Agriculture. In: B. Metz et al. (Eds.) Climate Change 2007: Mitigation. Contribution of Working Group III to the Fourth Assessment Report of the Intergovernmental Panel on Climate Change. Cambridge University Press, Cambridge, United Kingdom and New York, NY.

WÓJCIK-GRONT E. 2015: Territorial analysis of agricultural greenhouse gas emission in Poland. Appl. Ecol. Environ. Res. 13 (2): 417-425.

WÓJCIK-GRONT E., GRONT D. 2014: Assessing uncertainty in the Polish agricultural greenhouse gas emission inventory using Monte Carlo simulation. Outlook Agr. 43 (1): 61-65.
Streszczenie: Analiza przestrzenna emisji gazów cieplarnianych pochodzenia rolniczego na poziomie gmin w catej Polsce. Polska jest zobowiązana do corocznego raportowania krajowej emisji gazów cieplarnianych (GHG) w formie Krajowych Raportów Inwentaryzacyjnych (NIR) do Sekretariatu Konwencji Klimatycznej (UNFCCC). Całkowita emisja GHG w kraju pochodzi z wielu sektorów gospodarki. Jednym $\mathrm{z}$ nich jest rolnictwo. W prezentowanej pracy metodologia opracowana przez Międzyrządowy Zespół ds. Zmian Klimatu (IPCC) została użyta do oszacowania przestrzennego zróżnicowania emisji gazów cieplarnianych pochodzących $\mathrm{z}$ rolnictwa $\mathrm{w}$ całej Polsce na poziomie gmin. Obliczono wielkości emisji metanu, podtlenku azotu oraz dwutlenku wegla pochodzacych $\mathrm{z}$ rolnictwa w każdej z 2173 polskich gmin. Następnie wielkości te zostały przeliczone na ekwiwalenty dwutlenku węgla, zsumowane i dzięki temu otrzymano całkowitą emisję z rolnictwa w każdej gminie. Autorzy pracy użyli danych na temat zasobów gospodarstw i charakterystyki systemów rolniczych w gminach ze Spisu Rolnego z 2010 roku (NAC2010), które zostały zebrane przez Główny Urząd Statystyczny w Polsce (GUS). Wyniki obliczeń naniesiono na mape i po raz pierwszy dla Polski otrzymano rozkład przestrzenny emisji rolniczych gazów cieplarnianych na poziomie gmin. Największą emisję GHG z rolnictwa zaobserwowano w rejonach Podlasia i Wielkopolski. Jest ona związana z dużą intensywnością rolniczej produkcji zwierzęcej i roślinnej w tych rejonach.

Slowa kluczowe: rozkład przestrzenny, GHG, GWP, rolnictwo, UNFCCC, IPCC

MS received: 13.07.2017

MS accepted: 29.12.2017

\section{Authors' address:}

Elżbieta Wójcik-Gront

Katedra Doświadczalnictwa i Bioinformatyki

Wydział Rolnictwa i Biologii

Szkoła Główna Gospodarstwa Wiejskiego

w Warszawie

ul. Nowoursynowska 159, 02-776 Warsaw

Poland

e-mail: ewojcik.gront@gmail.com 